BeNTHAM OPEN
CrossMark
Content list available at: www.benthamopen.com/TOBIOTJ/
DOI: $10.2174 / 1874070701812010140,2018,12,140-153$

REVIEW ARTICLE

\title{
Aluminium Adjuvants - A Nanomaterial used as Adjuvants in Human Vaccines for Decades
}

\author{
Ravi Danielsson, Tove Sandberg and Håkan Eriksson* \\ Department of Biomedical Science, Faculty of Health and Society, Malmö University, SE-205 06 Malmö, Sweden
}

Received: February 02, 2017

Revised: March 01, 2017

Accepted: March 3, 2017

\begin{abstract}
:
Background:

Aluminium salts have been used for decades in vaccines as adjuvants to facilitate the adaptive immune response against coadministered antigens. Two types of aluminium adjuvant are mostly used, aluminium oxyhydroxide and aluminium hydroxyphosphate. Both types of aluminium adjuvant consist of nanoparticles that form loose, micrometre sized aggregates at circumneutral $\mathrm{pH}$.
\end{abstract}

Aluminium adjuvants constitute a well-documented example of administration of nanomaterials to humans with infrequent side effects and a safety record generally regarded as excellent. However, despite its prolonged use in human and veterinary medicine, the mechanisms behind the enhanced response and the immune stimulatory effect are still by and large unknown.

\section{Methods:}

The present paper reviews existing ideas regarding the immunostimulatory effects of aluminium adjuvants, with a focus on the induction of an inflammatory response by cellular stress. Reviewed information was obtained from peer-reviewed scientific papers published in 1988 to date with one exception, a paper published 1931.

\section{Results:}

Cellular stress causes extra cellular signalling of Danger Associated Molecular Patterns (DAMPs) and upon phagocytosis of aluminium adjuvants the cells need to manage the ingested particles.

\section{Conclusion:}

A persistent intracellular accumulation of aluminium adjuvants will be a solid depository of sparingly soluble aluminium salts maintaining a constant concentration of $\mathrm{Al}^{3+}$ ions in the cytoplasm and this will affect multiple biochemical processes. The cell will be under constant stress and DAMP signalling will occur and we would like to suggest the maintenance of a constant concentration $\mathrm{Al}^{3+}$ ions in the cytoplasm as a general underlying feature of the immune stimulation properties of aluminium adjuvants.

Keywords: Aluminium adjuvants, Cellular stress, DAMP, Vaccine, Immunostimulatory effects, $\mathrm{Al}^{3+}$ ions.

\section{INTRODUCTION}

Vaccines, one of the greatest achievements of medicine, have a major impact on public health worldwide, saving millions of people from disease and premature death. In attenuated and inactivated vaccines, such as the tuberculosis and the Salk polio vaccine, the vaccine contains not only the pertinent antigens but also endogenous immune stimulants acting as adjuvants. However, in vaccines containing isolated and purified antigen such as tetanus, diphtheria, and pertussis vaccines, the formulations require addition of exogenous adjuvants and to that end, aluminium salts have been

\footnotetext{
${ }^{*}$ Address correspondence to this author at the Department of Biomedical Science, Faculty of Health and Society, Malmö University, SE-205 06 Malmö, Sweden, Tel: +46406657925; E-mail hakan.eriksson@mah.se
} 
used for decades to facilitate an adaptive immune response against co-administered antigens.

The current and main types of aluminium salts used as adjuvants in vaccine formulations are aluminium oxyhydroxide and aluminium hydroxyphosphate. Both types of aluminium adjuvants consist of nanoparticles that form loose, micrometre sized aggregates at circumneutral $\mathrm{pH}$; the physical and chemical properties are however quite different.

Aluminium oxyhydroxide consists of needle-like crystallites, $4.5 \mathrm{~nm}$ x $2.2 \mathrm{~nm}$ x $10 \mathrm{~nm}$ in size [1], which form micrometre sized aggregates under physiological conditions. The aggregated aluminium oxyhydroxide particles have a large surface area with a positive surface charge at neutral $\mathrm{pH}$.

Aluminium hydroxyphosphate is amorphous, forming plate-like nanoparticles with a diameter of $50 \mathrm{~nm}$ [2], which aggregate and form loosely unified micrometre sized particles under physiological conditions. The aggregated aluminium hydroxyphosphate particles have a large surface area at neutral $\mathrm{pH}$, however, the surface charge is negative and thereby opposite in charge compared to aluminium oxyhydroxide particles.

Adsorption of protein antigens onto aluminium adjuvants are mediated through hydrophobic and van der Waals forces, electrostatic interactions, and by ligand exchange [3]. An initial electrostatic interaction will lead to adsorption of the antigen, which upon rearrangements on the adjuvant surface results in an antigen adsorbed onto the adjuvant particles through multi-point attachments, mediated by a mixture of electrostatic as well as hydrophobic and van der Waals interactions. Since, the commonly used aluminium adjuvants have opposite surface charges, aluminium oxyhydroxide is generally used as adjuvant in combination with antigens having an isoelectric point less than 7 whereas aluminium hydroxyphosphate is used with antigens having an isoelectric point greater than 7.

For many years, it was believed that the mechanism of action of aluminium adjuvants was due to adsorption of the antigen to the adjuvant and thereby facilitating antigen presentation and at the same time forming an antigen depot at the injection site, prolonging the exposure of antigen to the immune system. The depot hypothesis was proposed as early as 1931 by Glenny, Buttle, and Stevens [4], however, the depot effect of aluminium adjuvants is today regarded as not being likely since:

- Within hours after administration most of the antigen diffuses away from the injection site [5].

- The half-life of antigen in situ is not increased due to administration of antigen adsorbed on aluminium adjuvants [3].

- The magnitude of the immune response is not dependent on the adjuvant remaining at the injection site for more than a few hours [6].

- Fibrin-dependent nodules induced by aluminium adjuvants at the injection site is not a requirement of an immune response [7].

Instead, many reports have been made regarding infiltrating cells at the injection site showing both the accumulation of granulocytes, monocytes, macrophages and dendritic cells [8 - 10] and increased amounts of inflammatory chemokines and cytokines at the injection site $[9,11,12]$. Today the predominant hypothesis is that the aluminium adjuvants induce inflammation at the injection site and several reviews have been published regarding the induction of an inflammatory reaction as the mechanism behind the immune stimulatory properties of aluminium adjuvants [13 21]. Induction of an inflammatory response is consistent with Polly Matzinger's proposal in 1994, that immune activation not only needs to be initiated by microbial infections but also by the recognition of molecules associated with danger [22]. Danger molecules such as Pathogen Associated Molecular Patterns (PAMPs), driving inflammation and initiating an adaptive immune response were soon identified [23, 24], and today the danger signals also include alarm signals derived from endogenous molecules expressed at elevated levels upon danger, damage, stress, injury, or necrosis $[25,26]$.

The involvement of DAMP and alarm molecules in the initiation of inflammation and thereby the induction of an adaptive immune response has to some extent focused the research and lead to the development of adjuvants derived from PAMP structures, inducing an inflammatory response at the injection site [27, 28]. An innate immune response is induced after recognition of PAMP molecules by Toll-Like Receptors (TLR) and agonists against TLRs have been utilized as adjuvants in vaccine formulations. Derivatives of LPS such as Monophosphoryl Lipid A (MPLA) and oligonucleotides as CpG with specificities against TLR4 and TLR9 respectively, have been used in both experimental and approved vaccine formulations. 
The initiation of an inflammatory and a subsequent adaptive immune response caused by aluminium adjuvants has been suggested to be mediated by; the activation of caspase -1 and the NLRP3 inflammasome [29]; formation of Reactive Oxygen Species, ROS, either in the phagosomes [30] or by the mitochondrial electron transport chain [31 - 33] and their subsequent release into the cytosol; rupture of phagolysosomes by aluminium adjuvants facilitating release of proteases such as cathepsin B into the cytoplasm [34]; formation of lipid rafts in the cell membranes of antigen presenting cells, APCs [35]. However, none of these suggested mechanisms have been verified as a general mechanism initiating the immune stimulatory features of aluminium adjuvants since no reduction of the immune response has been observed in vivo after cellular depletions [36] or in mice lacking NALP3 inflammasomes [11, 37] and cathepsin B [38].

At the injection site, aluminium adjuvants have been shown to induce necrosis and cell injury [39 - 41]. Dead or dying cells at the injection site will release DAMP structures, sometimes referred to as alarmins [42], corroborating the induction of inflammation as a central cause of the adjuvant properties of aluminium adjuvants and indeed, the involvement of DAMP and alarmins such as DNA [39], ATP [43] and HSP70 [44] in the immune response induced by aluminium adjuvants has been reported. Accordingly, cell injury and necrosis caused by aluminium adjuvants will induce a sterile inflammation [45], however, DAMP or alarmin molecules can also be released upon cellular stress [46, 47], in the absence of cell death and necrosis.

Regarding the depot effect of aluminium adjuvants, clearance of the adjuvant is mediated by a complete solubilisation into $\mathrm{Al}^{3+}$ ions. Ions are quickly eliminated from the body and using a radioactive isotope of aluminium and a soluble aluminium salt, aluminium citrate, $83 \%$ of intravenously injected aluminium was eliminated after 13 days [48]. However, in a vaccine, aluminium adjuvants are injected as aggregates of aluminium salts with a solubility of less than one $\mu \mathrm{g} \mathrm{Al} l^{3+} / \mathrm{ml}$ [49] and in animal experiments injection of aluminium adjuvants have resulted in the clearance of no more than $6 \%$ of the aluminium 28 days after administration of aluminium oxyhydroxide, although a somewhat higher elimination was obtained using aluminium hydroxyphosphate showing $28 \%$ elimination at day 28 [50]. Information regarding the bio-distribution of aluminium adjuvants after injection and their elimination is limited, however, upon endocytosis and encapsulation in granulomas at the injection site, an elimination rate completely different from the rate obtained using soluble aluminium citrate as tracer can be expected.

Cells of myeloid origin, i.e. neutrophils, macrophages, and dendritic cells, are efficient phagocytic cells and a quick uptake of aluminium adjuvants by myeloid cells occurs at the injection site [34, 35, 51, 52]. Several reports have shown long time persistent intracellular aluminium aggregates in macrophages after administration of aluminium adjuvants $[53,54]$ and in lymphoid organs, cells of myeloid origin have been shown to harbour aluminium aggregates [55, 56]. The cellular machinery will try to handle intracellular aluminium adjuvants and cellular stress can be anticipated in cells holding the challenging aluminium aggregates, and as previously mentioned, cellular stress induces expression of DAMP or alarmin molecules. DAMP molecules are not only released upon stress induced cell death [26, 45, 57 - 59], but also from living, although stressed cells [46, 60 - 62]. In this context, myeloid cells are well known to induce inflammation and to act as Antigen-Presenting Cells (APCs). Release of DAMP and alarmins from these cells fits well with the danger model by Matzinger in which injection of aluminium adjuvants results in a short-term inflammation inducing the adaptive immune system and could concomitantly trigger a long-term inflammation resulting in some of the autoimmune related pathological side effects (ASIA) reported to be caused by aluminium adjuvants [63, 64].

The mechanism behind the immune stimulating properties of aluminium adjuvants have been discussed and debated during decades and this review will focus on possible biochemical mechanisms inducing an initial cellular stress response due to exposure to aluminium adjuvants.

\section{CELLULAR IMPACTS DUE TO EXPOSURE AND INTERNALIZATION OF ALUMINIUM ADJUVANTS}

Aluminium adjuvants in vaccines consist of aggregated nanomaterial and the impact of nanoparticles on various cellular mechanisms has been reported in several reviews [65 - 68] while $\mathrm{Al}^{3+}$ ions have no essential role in any biological mechanism as far as is known. Aluminium salts and ions have only shown toxic effects at very high concentrations and are generally considered as posing low risk of inducing adverse effects. However, studies have suggested that long-term exposure of aluminium has adverse neurological effects [69, 70] and ASIA has been reported in relation to aluminium adjuvants $[63,64]$.

Inorganic solid state materials have been shown to affect the immune activation due to their physicochemical properties [71], and upon internalization into a cell, aluminium adjuvants may interfere with numerous and diverging 
biochemical and biological mechanisms. Fig. (1) outlines the various aspects that will be discussed in this review and in which aluminium adjuvants may initiate an inflammatory process and thereby an adaptive immune response.

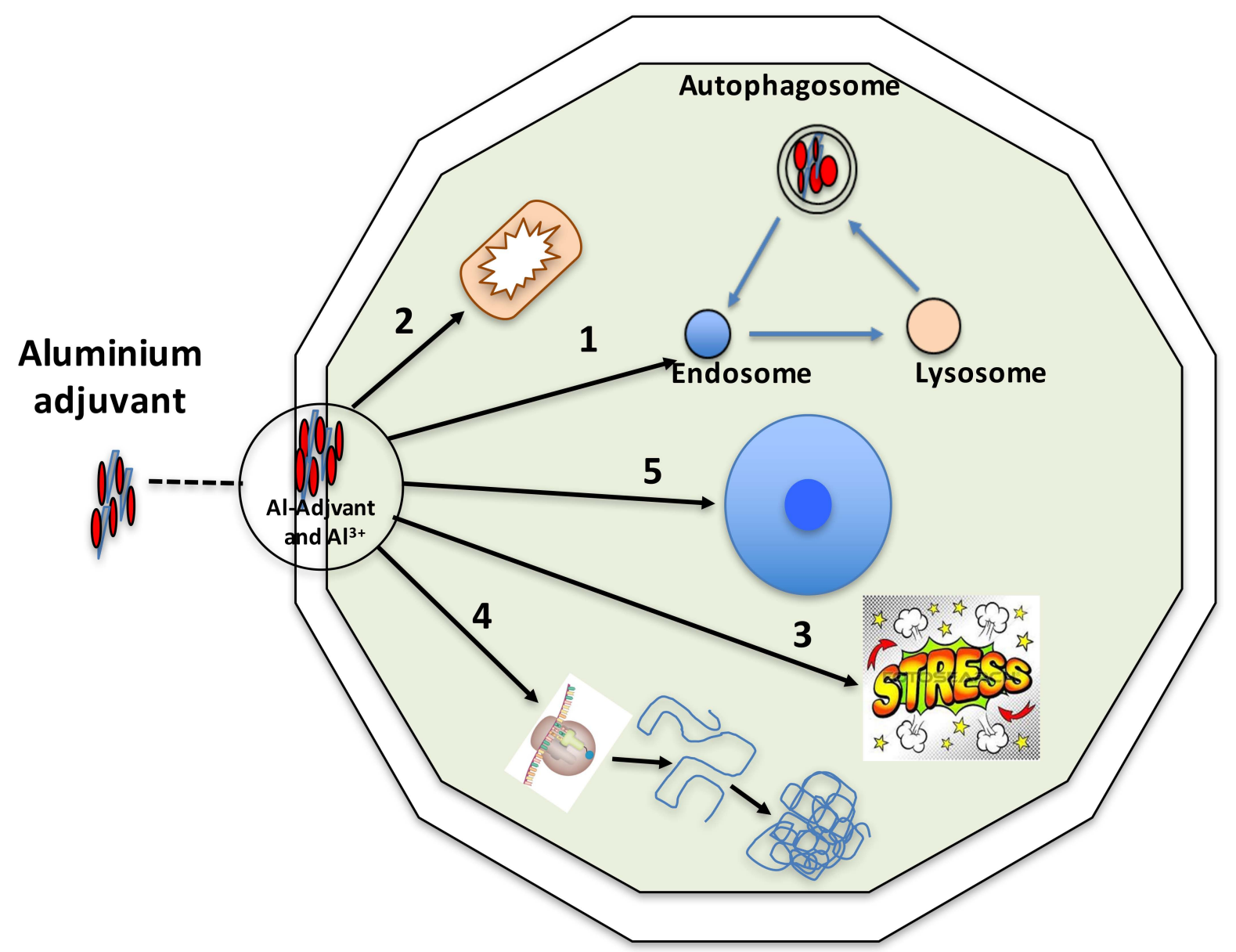

Fig. (1). Schematic picture showing internalization of Al adjuvants into a cell through an early phagosome containing Al-adjuvant aggregate(s) and due to encapsulation of the adjuvant also a saturated solution of $\mathrm{A}^{13+}$ ions. Upon entrance into the cell, Al-particles and dissolved $\mathrm{A}^{13+}$ ions can be expected to influence; 1) the endosomal pathway 2) mitochondrial function and activity 3) cellular stress functions 4) protein synthesis and folding 5) nuclear structure and function.

\subsection{The Endosomal Pathway, Early Endosome (Phagosome) to Lysosome (Phagolysosome)}

Upon injection aluminium adjuvants consist of micrometre sized aggregates, which are quickly recognized by phagocytosing cells and internalized [53, 72, 73]. Phagocytosing cells are mainly cells of the myeloid line which are potential professional APCs and phagocytosis of aluminium adjuvant may promote the survival of the cells [74].

Phagocytosis of aluminium adjuvants will, at the molecular level, give the cell a very high load of both antigen adsorbed on the adjuvant aggregates and of aluminium salts. The aluminium adjuvant consists of aggregated nanoparticles and once inside the phagosome an equilibrium will be established between various levels of aggregated nanoparticles and of soluble $\mathrm{Al}^{3+}$ ions. However, upon phagosome maturation into a phagolysosome, the milieu inside the vesicle entrapping the adjuvant aggregate will be altered. Maturation into a phagolysosome will change the protein and peptide content inside the vesicle and due to oxidative burst, change the redox potential in the vesicle. The $\mathrm{pH}$ will also drop, reflecting an increase of the $\mathrm{H}^{+}$concentration by several orders of magnitude. Taken together this will probably affect the aggregation level of nanoparticles forming the aluminium adjuvant and certainly the $\mathrm{Al}^{3+}$ concentration since a decrease in $\mathrm{pH}$ increases the solubility of the aluminium salts used as adjuvants. Both aluminium adjuvants and $\mathrm{Al}^{3+}$ ions have been reported to interact and destabilize lipid membranes [35, 51, 75, 76], and rupture of phagosomes and release of the content into the cytoplasm has been suggested as possible mechanism of aluminium adjuvants [34]. However, in this context it was only the release of the lysosomal protease cathepsin B that was 
discussed, not the release of nanoparticles of aluminium adjuvants or $\mathrm{Al}^{3+}$ ions. Release of aluminium adjuvants into the cytoplasm constitutes a source of nanoparticles at various degree of aggregation and thus a solid depository of sparingly soluble aluminium salts maintaining a constant concentration of $\mathrm{Al}^{3+}$ ions in the cytoplasm. Several reports have verified the presence of small amounts aluminium particles persistent in the cytoplasm [51 - 54, 77] and Mitchell et al. [68] have shown a strong upregulation of stress responses as a proactive defence against low loads of intra cellular nanoparticles. Several stress induced proteins have been identified as DAMP molecules and it should be considered that a cell with a low and persistent load of aluminium adjuvants will be a cell with a continuous increased stress response and thereby a potential inducer of a sterile inflammation.

Micrometre sized aggregates of aluminium adjuvants will not be degraded inside a phagolysosome and in a situation with or without disruption of the lysosomal membrane, initiation of an autophagosomal process will be anticipated as an attempt to handle the particles [78 - 80]. The autophagosomal pathway induces a new compartmentalization of the particles, including re-acidification and relocation of the aluminium adjuvant in autophagosomes. Without solubilisation, this process will be repeated and each cycle will drain the cell of energy. Both the phagosomal and the autophagosomal pathways are energy consuming primarily owing to the acidification of the vesicles and increased mitochondrial activity after phagocytosis of aluminium adjuvants has been reported [81].

Solubilisation of aluminium adjuvants occurs at the decreased $\mathrm{pH}$ inside the phagosomal/autophagosomal vesicles, however, upon release into the cytoplasm, the solubility will be reduced as the circumneutral $\mathrm{pH}$ is re-established. In any event, a constant amount of $\mathrm{Al}^{3+}$ ions will be present in the cytoplasm, controlled by the release of ions from solid aluminium salts. As other metal ions, aluminium ions interact with all kinds of biomolecules and can be expected to interfere with numerous biochemical events and mechanisms in the cell.

\subsection{Mitochondrial Function and Activity}

The energy production of a cell takes place in the mitochondria, and to maintain the function of the mitochondria, the inner mitochondrial membrane potential and the permeability status of the membranes must be sustained. The formation of ATP is driven by a chemiosmotic gradient established by an electron transport chain in the inner mitochondrial membrane and the major generation of ROS occurs at the electron transport chain as a by-product of respiration [82, 83]. At high cellular energy demand, the generation of mitochondrial ROS will increase and several reports have shown that nanoparticles induce and increase mitochondrial ROS generation [84 - 86]. This fits well with the assumption that non- or slowly degradable particles like aluminium adjuvants increase the energy consumption of the cells and reports have shown the accumulation of $\mathrm{Al}_{2} \mathrm{O}_{3}$ nanoparticles in autophagosomes [87].

Nanoparticles of aluminium adjuvants are more potent adjuvants than their corresponding microparticles and treatment with nanoparticles of aluminium adjuvants establishes a higher intracellular aluminium content [84]. Aluminium adjuvants and $\mathrm{Al}^{3+}$ ions impair the stability of lipid membranes $[35,51,75,76]$ and both nano- and microparticles of aluminium adjuvants induce lysosomal rupture and trigger increased levels of intracellular ROS. However, both particle sizes have been shown to be equally efficient in inducing lysosomal rupture and intracellular ROS content [84]. Solubilisation of the adjuvants into aluminium ions is a limiting feature and although treatment with nanoparticles results in a higher level of intra cellular aluminium, the cytoplasmic concentration of aluminium ions can be expected to be the same regardless whether the intracellular delivery is mediated by nano- or microparticles. Instead the time span, during which a saturated level of intracellular $\mathrm{Al}^{3+}$ ions remains, will be longer using nanoparticles. The major impact on mitochondria can then be expected to be mediated by Al ions, however, in mammalian systems the effect of intra cellular Al ions is challenging to investigate since they hardly penetrate the cell membrane (unless they are delivered through endocytosis as an aggregated aluminium salt). Instead conclusion can be drawn from experiments using plant materials in which intracellular concentrations of aluminium ions can be maintained. Several biochemical processes can be considered as the same or very similar in plant and mammalian cells and in plants, aluminium ions have been shown to cause ROS bursts and deterioration of the mitochondrial inner membrane potential [88, 89]. Al ions also increased the permeability of the mitochondrial outer membrane, triggered the release of cytochrome c from mitochondria to the cytoplasm, and caused activation of caspase 3-like activity and fragmentation of DNA. Several other reports have shown similar results in plant material with a collapse of the inner mitochondrial membrane potential and the release of cytochrome $\mathrm{c}$ from mitochondria to cytoplasm [90].

The function of the mitochondria is affected by $\mathrm{Al}^{3+}$ in plants and the same can be expected to be valid in mammalian cells and dysfunctional mitochondria have been detected upon chronic exposure to aluminium ions in mammalians [91]. Damaged and non-functional mitochondria are removed through autophagy, a process called 
mitophagy [92], and oxidized mitochondrial DNA, released into the cytoplasm due to damaged mitochondria evading mitophagy, activates the inflammasome and the cell becomes a potential inflammatory cell [31, 33]. Mitochondria function and their implication in the induction and continuation of inflammation has received increased attention [93] and the mitochondria are also pronounced sources of potential DAMP molecules and structures such as ATP, N-formyl peptides, and mtDNA [58]. Aluminium adjuvants escaping the endosomal pathway into the cytoplasm, and especially the establishment of a long lasting saturated concentration of aluminium ions in the cytoplasm, will have consequences on the mitochondrial performance and may have a pronounced influence on the manifestation and continuation of an inflammatory response.

\subsection{Cellular Stress Functions}

Cellular stress responses are physiological responses to an event, involving unfamiliar stimuli that affect the cells in different ways and initiate production and release of various proteins by the cell to contain or overcome the provocation. Polly Matzinger proposed the Danger model 1994 in which she suggests that the immune system is more concerned with damage than with foreignness, and that the immune system is called into action by alarm signals from injured tissues. These alarm signals can be constitutive or inducible, intracellular or secreted, or even a part of the extracellular matrix. Healthy tissues induce tolerance, but when damaged, they stimulate inflammation, and initiate an adaptive immune response [94]. Examples of proteins associated with a stress response in this context are Heat Shock Proteins (HSP) of different molecular size, S100s, calreticulin, High-Mobility Group Box 1 Protein (HMGB1), GlucoseRegulated Proteins (GRP), and mitochondrial components as previously described [60].

Today the use of adjuvants has become vital as additives in vaccine formulations and an awareness of their interactions with PAMP and DAMP biological mechanisms has become apparent [95]. Particles can cause a sterile inflammation, and cells that are not inflammatory become pro-inflammatory when they are dead because of their release of intracellular molecules acting as DAMPs.

Aluminum adjuvants cause cell injury resulting in the release of cellular contents such as uric acid, ATP, and cellular DNA. The thus released cellular contents provide molecular danger signals that cause sterile inflammation and activate dendritic cells by binding to pattern recognition receptors [39, 43, 96]. Stress induced by aluminium adjuvants in vivo as a mechanism of adjuvanticity has been proposed. In this respect, subcutaneous administration of aluminium adjuvants induced increased expression of both cell surface and intracellular HSP70 by splenic dendritic cells, and the adjuvant induced immune response was reduced if the expression of HSP70 was inhibited. HSP70 is a hallmark DAMP molecule and these results associate DAMP induction, cellular stress, and aluminium adjuvants [44]. Furthermore, upon oral intake of $\mathrm{Al}$ ions, the resulting prolonged exposure to $\mathrm{Al}$ ions affects biochemical processes in the cell causing cumulative sub lethal effects that activate different chaperones in the rat kidney and liver. A clear induction of HSP72 was detected in liver and HSP25 in the kidney whereas GRP75 was detected in both liver and kidney [97].

At the administration site of a vaccine, an initial high concentration of various aluminium species can be anticipated, causing necrosis of resident and initially infiltrating phagocytosing cells. Upon diffusion and dilution by interstitial fluid, the concentration of aluminium species will be reduced and the cells will be exposed to sub-toxic concentrations. At this point, phagocytosing cells will accumulate the adjuvant in phagosomes and upon release or escape, micro- and nanometre sized aggregates as well as a constant concentration of $\mathrm{Al}^{3+}$ ions will be maintained in the cytoplasm as previously described. Low amounts of intra cellular nanoparticles have been shown to induce a strong upregulation of genes encoding stress response proteins, such as heat shock proteins and other chaperones [68]. However, proinflammatory signalling by DAMP molecules can also be mediated by secretion of existing intracellular DAMP molecules as shown by the inflammatory response triggered by HMGB1 [26, 98], and the DAMP signalling is thus not initiated by gene regulation. Consequently, approaches based on proteomics are needed to understand cellular stress responses and DAMP induction underlying the immune stimulating properties of aluminium adjuvants [99].

Cells must survive a variety of stressful conditions, and interference by aluminium ions, and other metal ions, can be expected to involve numerous biochemical events and mechanisms in the cell. $\mathrm{Al}^{3+}$ ions have been shown to bind to multifunctional proteins, e.g. calmodulin and S100 proteins [100], and it should be noted that upon secretion, proteins belonging to the S100 family show pro-inflammatory features and act as DAMPs [101, 102].

During cellular stress, there is an insistent and peremptory demand on protein synthesis and controlled folding, and several DAMP molecules are involved in these processes. HSPs are divided into seven classes, and exercise chaperone function by stabilizing new proteins to ensure correct folding, and aiding in the refolding of damaged proteins [103]. 
Calreticulin is another protein located in the endoplasmatic reticulum with chaperon properties and both HSPs and calreticulin are DAMPs with pro-inflammatory abilities [58, 104]. These molecules may very well be targets of aluminium ions resulting in changed conformation, modified function, and cellular re-localization. Hence, as suggested by these results, cytoplasmic nanometre aggregates of aluminium adjuvants in general, and aluminium ions in particularly, impact several biochemical processes, provoking cellular stress and expression of DAMP molecules without causing cell death.

\subsection{Protein Synthesis and Folding}

The protein content of a cell is regulated by gene expression, synthesis, re-folding, and degradation, and nanoparticles as well as aluminium ions have been shown to affect the conformation of proteins [100, 105, 106]. Conformational changes will increase the demand for cellular protein synthesis and re-folding operations, and consequently, upregulation of the syntheses of proteins and chaperons will result.

Aluminium adjuvants in the cytoplasm will form a solid depository of sparingly soluble aluminium salts, maintaining a constant concentration of $\mathrm{Al}^{3+}$ ions over a long period. Protocols designed to study the effects of a constant low concentration of aluminium ions in the cytoplasm of mammalian cells are challenging. The required experimental set up is less challenging when working with plant cells and several reports have shown that aluminium ions affect the cellular content of proteins related to stress/defence, signal transduction, transport, and folding [107, 108]. Chaperones are upregulated and hence, proteins of the HSP family, e.g. HSP70 and HSP90, are utilized by plant cells to handle aluminium ion induced stress [109 - 111]. The increased value of chaperone systems in plants to manage intracellular aluminium ions is probably mirrored by mammalian cells and an interesting aspect is that several components of the chaperone systems also function as DAMP molecules in a mammalian context.

\subsection{Nuclear Structure and Function}

Particulate aluminium adjuvants have not been demonstrated experimentally in the nucleus of adjuvant exposed cells [10, 53 - 56] and nuclear DNA damage has been observed in mammalians only at aluminium ion concentrations several magnitudes higher than those expected from slow dissolution of a solid depository of aluminium adjuvants in the cytoplasm $[112,113]$. Increased gene expression of several genes has been monitored upon exposure to aluminium ions. In rat brain cells expression of genes related to mitochondrial respiration, including gene products also encoded by mitochondrial DNA [114] increased, and similar results on mitochondrial genes have been reported in plant cells [88].

Cellular uptake of nanoparticles also results in increased gene expression and the genes expressed are dependent on the surface charge of the particles and the amount nanoparticles accumulated intracellularly [68]. An interesting aspect is that microRNAs (miRNA) have been shown to be involved in the gene regulation of plant cells exposed to $\mathrm{Al}_{2} \mathrm{O}_{3}$ nanoparticles [115] and to our knowledge, there are no reports regarding miRNA based gene regulation upon cellular exposure to aluminium adjuvants.

\section{CONCLUSION}

Aluminium adjuvants have been used in vaccines during decades and yet no consensus has been reached regarding the mechanism of immune stimulation by aluminium salts. Several mechanisms have been proposed but none of these cover all the aspects of the immune response induced by aluminium adjuvants.

This review has focused on the possible biological impacts on a cell of an intra cellular depository of sparingly soluble aluminium salts, maintaining a constant concentration of $\mathrm{Al}^{3+}$ ions in the cytoplasm. A general cellular stress response resulting in the release of DAMP molecules can be expected due to the intracellular presence of particles and aluminium ions. The release of DAMP molecules will initially be mediated by necrotic cells that have succumbed to too high amounts intra cellular aluminium adjuvants, and later by livings cells that are able to handle the intra cellular amounts of adjuvants. Upon administration of vaccine myeloid cells, e.g. monocytes, macrophages, and dendritic cells accumulate aluminium adjuvants and since those cells are all potential APCs, they will become efficient inducers of an adjuvant based immune response. Aluminium adjuvants will upon phagocytosis deliver an antigen and at the same time convert the cells into DAMP expressing cells. On this basis, we would like to suggest the maintenance of a constant concentration of $\mathrm{Al}^{3+}$ ions in the cytoplasm as a general underlying feature of the immune stimulation properties of aluminium adjuvants. The presence of a constant intracellular concentration of aluminium ions will affect multiple biochemical processes in the cell, efficiently inducing DAMP molecules in viable cells that otherwise manage to handle the presence of aluminium ions (Fig. 1). Other metal ions may also have the same intracellular cellular effect as $\mathrm{Al}^{3+}$ 
ions and thus mediate the induction of an immune response, and correlations between the immune stimulating properties and the physicochemical properties of inorganic crystalline materials containing metal ions have been shown [71]. However, in this report by Williams et.al, no information was given regarding the elimination, or lack of elimination, of the crystallites once phagocytosed, and no information was given regarding the expected metal ion concentration in the cytoplasm of a cell.

According to regulations, the maximal amount of aluminium adjuvant in the administered dose of a vaccine is 1.25 $\mathrm{mg} \mathrm{Al}$ per dose [116]. In general, a vaccine contains $0.5-1 \mathrm{mg}$ aluminium adjuvant per dose and the amount of aluminium adjuvant is designed to provide an excessive load of antigen. An inflammation is the inducer of an immune response and upon an adaptive immune activation, the inflammation is supposed to subside. However, if the inflammation persists, it may turn into a chronic inflammation with all the negative implications [117]. Side effects such as ASIA [63, 64] caused by aluminium adjuvants have raised concerns on the use of aluminium salts as adjuvants in vaccine formulations and a chronic inflammation induced by a constant intracellular concentration of $\mathrm{Al}^{3+}$ ions could be the core of the autoimmune related side effect observed. By lowering the amounts of aluminium adjuvants in the vaccine formulation, an efficient immune response may still be achieved, however, the amounts of aluminium adjuvants persisting intracellularly will be reduced and thus mitigate the induction of a chronic inflammation and the occurrence of adverse reactions.

\section{CONSENT FOR PUBLICATION}

Not applicable.

\section{CONFLICT OF INTEREST}

There are no conflicts of interest in the preparation of this manuscript. This research project is funded by Malmö University and the UK MRC.

\section{ACKNOWLEDGEMENTS}

We thank Prof. Zoltan Blum for helpful comments and discussions.

\section{REFERENCES}

[1] Johnston CT, Wang SL, Hem SL. Measuring the surface area of aluminum hydroxide adjuvant. J Pharm Sci 2002; 91(7): 1702-6. [http://dx.doi.org/10.1002/jps.10166] [PMID: 12115832]

[2] Burrell LS, Johnston CT, Schulze D, Klein J, White JL, Hem SL. Aluminium phosphate adjuvants prepared by precipitation at constant pH. Part I: Composition and structure. Vaccine 2000; 19(2-3): 275-81. [http://dx.doi.org/10.1016/S0264-410X(00)00160-2] [PMID: 10930682]

[3] Hem SL, Hogenesch H. Relationship between physical and chemical properties of aluminum-containing adjuvants and immunopotentiation. Expert Rev Vaccines 2007; 6(5): 685-98. [http://dx.doi.org/10.1586/14760584.6.5.685] [PMID: 17931150]

[4] Glenny AT, Buttle GAH, Stevens MF. Rate of disappearance of diphtheria toxoid injected into rabbits and guinea - pigs: Toxoid precipitated with alum. J Pathol Bacteriol 1931; 34(2): 267-75.

[http://dx.doi.org/10.1002/path.1700340214]

[5] Gupta RK, Chang A-C, Griffin P, Rivera R, Siber GR. In vivo distribution of radioactivity in mice after injection of biodegradable polymer microspheres containing 14C-labeled tetanus toxoid. Vaccine 1996; 14(15): 1412-6. [http://dx.doi.org/10.1016/S0264-410X(96)00073-4] [PMID: 8994315]

[6] Hutchison S, Benson RA, Gibson VB, Pollock AH, Garside P, Brewer JM. Antigen depot is not required for alum adjuvanticity. FASEB J 2012; 26(3): 1272-9.

[http://dx.doi.org/10.1096/fj.11-184556] [PMID: 22106367]

[7] Munks MW, McKee AS, Macleod MK, et al. Aluminum adjuvants elicit fibrin-dependent extracellular traps in vivo. Blood 2010; 116(24): 5191-9.

[http://dx.doi.org/10.1182/blood-2010-03-275529] [PMID: 20876456]

[8] Mosca F, Tritto E, Muzzi A, et al. Molecular and cellular signatures of human vaccine adjuvants. Proc Natl Acad Sci USA 2008; 105(30): 10501-6. [http://dx.doi.org/10.1073/pnas.0804699105] [PMID: 18650390]

[9] Kool M, Pétrilli V, De Smedt T, et al. Cutting edge: Alum adjuvant stimulates inflammatory dendritic cells through activation of the NALP3 inflammasome. J Immunol 2008; 181(6): 3755-9. [http://dx.doi.org/10.4049/jimmunol.181.6.3755] [PMID: 18768827] 
[10] Lu F, Hogenesch H. Kinetics of the inflammatory response following intramuscular injection of aluminum adjuvant. Vaccine 2013; 31(37): 3979-86. [http://dx.doi.org/10.1016/j.vaccine.2013.05.107] [PMID: 23770306]

[11] McKee AS, Munks MW, MacLeod MK, et al. Alum induces innate immune responses through macrophage and mast cell sensors, but these sensors are not required for alum to act as an adjuvant for specific immunity. J Immunol 2009; 183(7): $4403-14$. [http://dx.doi.org/10.4049/jimmunol.0900164] [PMID: 19734227]

[12] Korsholm KS, Petersen RV, Agger EM, Andersen P. T-helper 1 and T-helper 2 adjuvants induce distinct differences in the magnitude, quality and kinetics of the early inflammatory response at the site of injection. Immunology 2010; 129(1): 75-86. [http://dx.doi.org/10.1111/j.1365-2567.2009.03164.x] [PMID: 19824919]

[13] Brewer JM. (How) do aluminium adjuvants work? Immunol Lett 2006; 102(1): 10-5. [http://dx.doi.org/10.1016/j.imlet.2005.08.002] [PMID: 16188325]

[14] Marrack P, McKee AS, Munks MW. Towards an understanding of the adjuvant action of aluminium. Nat Rev Immunol 2009; 9(4): 287-93. [http://dx.doi.org/10.1038/nri2510] [PMID: 19247370]

[15] Reed SG, Bertholet S, Coler RN, Friede M. New horizons in adjuvants for vaccine development. Trends Immunol 2009; $30(1)$ : $23-32$. [http://dx.doi.org/10.1016/j.it.2008.09.006] [PMID: 19059004]

[16] Mbow ML, De Gregorio E, Valiante NM, Rappuoli R. New adjuvants for human vaccines. Curr Opin Immunol 2010; 22(3): 411-6. [http://dx.doi.org/10.1016/j.coi.2010.04.004] [PMID: 20466528]

[17] Hogenesch H. Mechanism of immunopotentiation and safety of aluminum adjuvants. Front Immunol $2013 ; 3: 406$. [http://dx.doi.org/10.3389/fimmu.2012.00406] [PMID: 23335921]

[18] Kool M, Fierens K, Lambrecht BN. Alum adjuvant: Some of the tricks of the oldest adjuvant. J Med Microbiol 2012; 61(Pt 7): 927-34 [http://dx.doi.org/10.1099/jmm.0.038943-0] [PMID: 22174375]

[19] Awate S, Babiuk LA, Mutwiri G. Mechanisms of action of adjuvants. Front Immunol 2013; $4: 114$. [http://dx.doi.org/10.3389/fimmu.2013.00114] [PMID: 23720661]

[20] Reed SG, Orr MT, Fox CB. Key roles of adjuvants in modern vaccines. Nat Med 2013; 19(12): 1597-608. [http://dx.doi.org/10.1038/nm.3409] [PMID: 24309663]

[21] Ghimire TR. The mechanisms of action of vaccines containing aluminum adjuvants: An in vitro vs in vivo paradigm. Springerplus 2015; 4: 181.

[http://dx.doi.org/10.1186/s40064-015-0972-0] [PMID: 25932368]

[22] Matzinger P. Tolerance, danger, and the extended family. Annu Rev Immunol 1994; 12: 991-1045. [http://dx.doi.org/10.1146/annurev.iy.12.040194.005015] [PMID: 8011301]

[23] Medzhitov R, Preston-Hurlburt P, Janeway CA Jr. A human homologue of the drosophila toll protein signals activation of adaptive immunity. Nature 1997; 388(6640): 394-7. [http://dx.doi.org/10.1038/41131] [PMID: 9237759]

[24] Medzhitov R, Janeway CA Jr. An ancient system of host defense. Curr Opin Immunol 1998; 10(1): 12-5. [http://dx.doi.org/10.1016/S0952-7915(98)80024-1] [PMID: 9523104]

[25] Pradeu T, Cooper EL. The danger theory: 20 years later. Front Immunol 2012; 3: 287. [http://dx.doi.org/10.3389/fimmu.2012.00287] [PMID: 23060876]

[26] Sangiuliano B, Pérez NM, Moreira DF, Belizário JE. Cell death-associated molecular-pattern molecules: Inflammatory signaling and control. Mediators Inflamm 2014; 2014: 821043. [http://dx.doi.org/10.1155/2014/821043] [PMID: 25140116]

[27] Di Pasquale A, Preiss S, Tavares Da Silva F, Garçon N. Vaccine adjuvants: From 1920 to 2015 and beyond. Vaccines (Basel) 2015; 3(2): 320-43. [http://dx.doi.org/10.3390/vaccines3020320] [PMID: 26343190]

[28] De Gregorio E, Caproni E, Ulmer JB. Vaccine adjuvants: Mode of action. Front Immunol 2013; 4: 214. [http://dx.doi.org/10.3389/fimmu.2013.00214] [PMID: 23914187]

[29] Li H, Nookala S, Re F. Aluminum hydroxide adjuvants activate caspase-1 and induce IL-1beta and IL-18 release. J Immunol 2007; 178(8): 5271-6. [http://dx.doi.org/10.4049/jimmunol.178.8.5271] [PMID: 17404311]

[30] Pollock JD, Williams DA, Gifford MA, et al. Mouse model of X-linked chronic granulomatous disease, an inherited defect in phagocyte superoxide production. Nat Genet 1995; 9(2): 202-9. [http://dx.doi.org/10.1038/ng0295-202] [PMID: 7719350]

[31] Nakahira K, Haspel JA, Rathinam VA, et al. Autophagy proteins regulate innate immune responses by inhibiting the release of mitochondrial DNA mediated by the NALP3 inflammasome. Nat Immunol 2011; 12(3): 222-30. [http://dx.doi.org/10.1038/ni.1980] [PMID: 21151103]

[32] Zhou R, Yazdi AS, Menu P, Tschopp J. A role for mitochondria in NLRP3 inflammasome activation. Nature 2011; 469(7329): 221-5. [http://dx.doi.org/10.1038/nature09663] [PMID: 21124315] 
[33] Shimada K, Crother TR, Karlin J, et al. Oxidized mitochondrial DNA activates the NLRP3 inflammasome during apoptosis. Immunity 2012; 36(3): 401-14.

[http://dx.doi.org/10.1016/j.immuni.2012.01.009] [PMID: 22342844]

[34] Hornung V, Bauernfeind F, Halle A, et al. Silica crystals and aluminum salts activate the NALP3 inflammasome through phagosomal destabilization. Nat Immunol 2008; 9(8): 847-56. [http://dx.doi.org/10.1038/ni.1631] [PMID: 18604214]

[35] Flach TL, Ng G, Hari A, et al. Alum interaction with dendritic cell membrane lipids is essential for its adjuvanticity. Nat Med 2011; 17(4): 479-87.

[http://dx.doi.org/10.1038/nm.2306] [PMID: 21399646]

[36] Mitchell LA, Henderson AJ, Dow SW. Suppression of vaccine immunity by inflammatory monocytes. J Immunol 2012; $189(12)$ : 5612-21. [http://dx.doi.org/10.4049/jimmunol.1202151] [PMID: 23136203]

[37] Franchi L, Núñez G. The Nlrp3 inflammasome is critical for aluminium hydroxide-mediated IL-1beta secretion but dispensable for adjuvant activity. Eur J Immunol 2008; 38(8): 2085-9. [http://dx.doi.org/10.1002/eji.200838549] [PMID: 18624356]

[38] Dostert C, Pétrilli V, Van Bruggen R, Steele C, Mossman BT, Tschopp J. Innate immune activation through Nalp3 inflammasome sensing of asbestos and silica. Science 2008; 320(5876): 674-7. [http://dx.doi.org/10.1126/science.1156995] [PMID: 18403674]

[39] Marichal T, Ohata K, Bedoret D, et al. DNA released from dying host cells mediates aluminum adjuvant activity. Nat Med 2011; 17(8): 996-1002.

[http://dx.doi.org/10.1038/nm.2403] [PMID: 21765404]

[40] McKee AS, Burchill MA, Munks MW, et al. Host DNA released in response to aluminum adjuvant enhances MHC class II-mediated antigen presentation and prolongs CD4 T-cell interactions with dendritic cells. Proc Natl Acad Sci USA 2013; 110(12): E1122-31. [http://dx.doi.org/10.1073/pnas.1300392110] [PMID: 23447566]

[41] Cain DW, Sanders SE, Cunningham MM, Kelsoe G. Disparate adjuvant properties among three formulations of “alum”. Vaccine 2013; 31(4): 653-60. [http://dx.doi.org/10.1016/j.vaccine.2012.11.044] [PMID: 23200935]

[42] Yang D, de la Rosa G, Tewary P, Oppenheim JJ. Alarmins link neutrophils and dendritic cells. Trends Immunol 2009; 30(11): 531-7. [http://dx.doi.org/10.1016/j.it.2009.07.004] [PMID: 19699678]

[43] Riteau N, Baron L, Villeret B, et al. ATP release and purinergic signaling: A common pathway for particle-mediated inflammasome activation. Cell Death Dis 2012; 3: e403.

[http://dx.doi.org/10.1038/cddis.2012.144] [PMID: 23059822]

[44] Wang Y, Rahman D, Lehner T. A comparative study of stress-mediated immunological functions with the adjuvanticity of alum. J Biol Chem 2012; 287(21): 17152-60. [http://dx.doi.org/10.1074/jbc.M112.347179] [PMID: 22474329]

[45] Rock KL, Latz E, Ontiveros F, Kono H. The sterile inflammatory response. Annu Rev Immunol 2010; 28: 321-42. [http://dx.doi.org/10.1146/annurev-immunol-030409-101311] [PMID: 20307211]

[46] Muralidharan S, Mandrekar P. Cellular stress response and innate immune signaling: Integrating pathways in host defense and inflammation. J Leukoc Biol 2013; 94(6): 1167-84. [http://dx.doi.org/10.1189/jlb.0313153] [PMID: 23990626]

[47] Rider P, Voronov E, Dinarello CA, Apte RN, Cohen I. Alarmins: feel the stress. J Immunol 2017; $198(4)$ : $1395-402$. [http://dx.doi.org/10.4049/jimmunol.1601342] [PMID: 28167650]

[48] Priest ND, Talbot RJ, Austin JG, et al. The bioavailability of 26Al-labelled aluminium citrate and aluminium hydroxide in volunteers. Biometals 1996; 9(3): 221-8. [http://dx.doi.org/10.1007/BF00817919] [PMID: 8696074]

[49] Rinella JV, White JL, Hem SL. Effect of pH on the elution of model antigens from aluminum-containing adjuvants. J Colloid Interface Sci 1998; 205(1): 161-5.

[http://dx.doi.org/10.1006/jcis.1998.5648] [PMID: 9710509]

[50] Flarend RE, Hem SL, White JL, et al. In vivo absorption of aluminium-containing vaccine adjuvants using 26Al. Vaccine 1997; 15(12-13): 1314-8. [http://dx.doi.org/10.1016/S0264-410X(97)00041-8] [PMID: 9302736]

[51] Rimaniol AC, Gras G, Verdier F, et al. Aluminum hydroxide adjuvant induces macrophage differentiation towards a specialized antigenpresenting cell type. Vaccine 2004; 22(23-24): 3127-35. [http://dx.doi.org/10.1016/j.vaccine.2004.01.061] [PMID: 15297065]

[52] Morefield GL, Tammariello RF, Purcell BK, et al. An alternative approach to combination vaccines: Intradermal administration of isolated components for control of anthrax, botulism, plague and staphylococcal toxic shock. J Immune Based Ther Vaccines 2008 ; 6: 5. [http://dx.doi.org/10.1186/1476-8518-6-5] [PMID: 18768085] 
[53] Gherardi RK, Coquet M, Cherin P, et al. Macrophagic myofasciitis lesions assess long-term persistence of vaccine-derived aluminium hydroxide in muscle. Brain 2001; 124(Pt 9): 1821-31. [http://dx.doi.org/10.1093/brain/124.9.1821] [PMID: 11522584]

[54] Verdier F, Burnett R, Michelet-Habchi C, Moretto P, Fievet-Groyne F, Sauzeat E. Aluminium assay and evaluation of the local reaction at several time points after intramuscular administration of aluminium containing vaccines in the Cynomolgus monkey. Vaccine 2005; 23(11): $1359-67$.

[http://dx.doi.org/10.1016/j.vaccine.2004.09.012] [PMID: 15661384]

[55] Crépeaux G, Eidi H, David MO, et al. Highly delayed systemic translocation of aluminum-based adjuvant in CD1 mice following intramuscular injections. J Inorg Biochem 2015; 152: 199-205. [http://dx.doi.org/10.1016/j.jinorgbio.2015.07.004] [PMID: 26384437]

[56] Eidi H, David MO, Crépeaux G, et al. Fluorescent nanodiamonds as a relevant tag for the assessment of alum adjuvant particle biodisposition. BMC Med 2015; 13: 144 .

[http://dx.doi.org/10.1186/s12916-015-0388-2] [PMID: 26082187]

[57] Chen GY, Nuñez G. Sterile inflammation: Sensing and reacting to damage. Nat Rev Immunol 2010; 10(12): 826-37. [http://dx.doi.org/10.1038/nri2873] [PMID: 21088683]

[58] Krysko DV, Agostinis P, Krysko O, et al. Emerging role of damage-associated molecular patterns derived from mitochondria in inflammation. Trends Immunol 2011; 32(4): 157-64.

[http://dx.doi.org/10.1016/j.it.2011.01.005] [PMID: 21334975]

[59] Zelenay S, Reis e Sousa C. Adaptive immunity after cell death. Trends Immunol 2013; 34(7): 329-35. [http://dx.doi.org/10.1016/j.it.2013.03.005] [PMID: 23608152]

[60] Vénéreau E, Ceriotti C, Bianchi ME. DAMPs from Cell Death to New Life. Front Immunol 2015; 6: 422. [http://dx.doi.org/10.3389/fimmu.2015.00422] [PMID: 26347745]

[61] Srikrishna G, Freeze HH. Endogenous damage-associated molecular pattern molecules at the crossroads of inflammation and cancer. Neoplasia 2009; 11(7): 615-28.

[http://dx.doi.org/10.1593/neo.09284] [PMID: 19568407]

[62] Garg AD, Martin S, Golab J, Agostinis P. Danger signalling during cancer cell death: Origins, plasticity and regulation. Cell Death Differ 2014; 21(1): 26-38. [http://dx.doi.org/10.1038/cdd.2013.48] [PMID: 23686135]

[63] Agmon-Levin N, Paz Z, Israeli E, Shoenfeld Y. Vaccines and autoimmunity. Nat Rev Rheumatol 2009; 5(11): 648-52. [http://dx.doi.org/10.1038/nrrheum.2009.196] [PMID: 19865091]

[64] Shoenfeld Y, Agmon-Levin N. 'ASIA' - autoimmune/inflammatory syndrome induced by adjuvants. J Autoimmun 2011; 36(1): 4-8. [http://dx.doi.org/10.1016/j.jaut.2010.07.003] [PMID: 20708902]

[65] Gregory AE, Titball R, Williamson D. Vaccine delivery using nanoparticles. Front Cell Infect Microbiol $2013 ; 3: 13$. [http://dx.doi.org/10.3389/fcimb.2013.00013] [PMID: 23532930]

[66] Weissleder R, Nahrendorf M, Pittet MJ. Imaging macrophages with nanoparticles. Nat Mater 2014; $13(2)$ : $125-38$. [http://dx.doi.org/10.1038/nmat3780] [PMID: 24452356]

[67] Zhao L, Seth A, Wibowo N, et al. Nanoparticle vaccines. Vaccine 2014; 32(3): 327-37. [http://dx.doi.org/10.1016/j.vaccine.2013.11.069] [PMID: 24295808]

[68] Mitchell HD, Markillie LM, Chrisler WB, et al. Cells respond to distinct nanoparticle properties with multiple strategies as revealed by singlecell RNA-seq. ACS Nano 2016; 10(11): 10173-85. [http://dx.doi.org/10.1021/acsnano.6b05452] [PMID: 27788331]

[69] Willhite CC, Karyakina NA, Yokel RA, et al. Systematic review of potential health risks posed by pharmaceutical, occupational and consumer exposures to metallic and nanoscale aluminum, aluminum oxides, aluminum hydroxide and its soluble salts. Crit Rev Toxicol 2014; 44(Suppl. 4): 1-80.

[http://dx.doi.org/10.3109/10408444.2014.934439] [PMID: 25233067]

[70] Krewski D, Yokel RA, Nieboer E, et al. Human health risk assessment for aluminium, aluminium oxide, and aluminium hydroxide. J Toxicol Environ Health B Crit Rev 2007; 10(Suppl. 1): 1-269. [http://dx.doi.org/10.1080/10937400701597766] [PMID: 18085482]

[71] Williams GR, Fierens K, Preston SG, et al. Immunity induced by a broad class of inorganic crystalline materials is directly controlled by their chemistry. J Exp Med 2014; 211(6): 1019-25. [http://dx.doi.org/10.1084/jem.20131768] [PMID: 24799501]

[72] Morefield GL, Sokolovska A, Jiang D, HogenEsch H, Robinson JP, Hem SL. Role of aluminum-containing adjuvants in antigen internalization by dendritic cells in vitro. Vaccine 2005; 23(13): 1588-95. [http://dx.doi.org/10.1016/j.vaccine.2004.07.050] [PMID: 15694511]

[73] Mold M, Eriksson H, Siesjö P, Darabi A, Shardlow E, Exley C. Unequivocal identification of intracellular aluminium adjuvant in a monocytic THP-1 cell line. Sci Rep 2014; 4: 6287. [http://dx.doi.org/10.1038/srep06287] [PMID: 25190321] 
[74] Hamilton JA, Byrne R, Whitty G. Particulate adjuvants can induce macrophage survival, DNA synthesis, and a synergistic proliferative response to GM-CSF and CSF-1. J Leukoc Biol 2000; 67(2): 226-32. [http://dx.doi.org/10.1002/jlb.67.2.226] [PMID: 10670584]

[75] Goto N, Kato H, Maeyama J, Eto K, Yoshihara S. Studies on the toxicities of aluminium hydroxide and calcium phosphate as immunological adjuvants for vaccines. Vaccine 1993; 11(9): 914-8. [http://dx.doi.org/10.1016/0264-410X(93)90377-A] [PMID: 8212836]

[76] Bazzoni GB, Bollini AN, Hernández GN, Contini MdelC, Chiarotto MM, Rasia ML. In vivo effect of aluminium upon the physical properties of the erythrocyte membrane. J Inorg Biochem 2005; 99(3): 822-7. [http://dx.doi.org/10.1016/j.jinorgbio.2004.12.012] [PMID: 15708804]

[77] Mile I, Svensson A, Darabi A, Mold M, Siesjö P, Eriksson H. Al adjuvants can be tracked in viable cells by lumogallion staining. J Immunol Methods 2015; 422: 87-94. [http://dx.doi.org/10.1016/j.jim.2015.04.008] [PMID: 25896212]

[78] Stern ST, Adiseshaiah PP, Crist RM. Autophagy and lysosomal dysfunction as emerging mechanisms of nanomaterial toxicity. Part Fibre Toxicol 2012; 9: 20 . [http://dx.doi.org/10.1186/1743-8977-9-20] [PMID: 22697169]

[79] Wirawan E, Vanden Berghe T, Lippens S, Agostinis P, Vandenabeele P. Autophagy: For better or for worse. Cell Res 2012; $22(1)$ : 43-61. [http://dx.doi.org/10.1038/cr.2011.152] [PMID: 21912435]

[80] Deretic V. Autophagy as an innate immunity paradigm: expanding the scope and repertoire of pattern recognition receptors. Curr Opin Immunol 2012; 24(1): 21-31.

[http://dx.doi.org/10.1016/j.coi.2011.10.006] [PMID: 22118953]

[81] Ohlsson L, Exley C, Darabi A, Sandén E, Siesjö P, Eriksson H. Aluminium based adjuvants and their effects on mitochondria and lysosomes of phagocytosing cells. J Inorg Biochem 2013; 128: 229-36. [http://dx.doi.org/10.1016/j.jinorgbio.2013.08.003] [PMID: 23992993]

[82] Kowaltowski AJ, de Souza-Pinto NC, Castilho RF, Vercesi AE. Mitochondria and reactive oxygen species. Free Radic Biol Med 2009; 47(4): 333-43. [http://dx.doi.org/10.1016/j.freeradbiomed.2009.05.004] [PMID: 19427899]

[83] Murphy MP. How mitochondria produce reactive oxygen species. Biochem J 2009; 417(1): 1-13. [http://dx.doi.org/10.1042/BJ20081386] [PMID: 19061483]

[84] Ruwona TB, Xu H, Li X, Taylor AN, Shi YC, Cui Z. Toward understanding the mechanism underlying the strong adjuvant activity of aluminum salt nanoparticles. Vaccine 2016; 34(27): 3059-67. [http://dx.doi.org/10.1016/j.vaccine.2016.04.081] [PMID: 27155490]

[85] Poborilova Z, Opatrilova R, Babula P. Toxicity of aluminium oxide nanoparticles demonstrated using a BY-2 plant cell suspension culture model. Environ Exp Bot 2013; 91: 1-11. [http://dx.doi.org/10.1016/j.envexpbot.2013.03.002]

[86] Yamamoto Y, Kobayashi Y, Devi SR, Rikiishi S, Matsumoto H. Aluminum toxicity is associated with mitochondrial dysfunction and the production of reactive oxygen species in plant cells. Plant Physiol 2002; 128(1): 63-72. [http://dx.doi.org/10.1104/pp.010417] [PMID: 11788753]

[87] Li H, Li Y, Jiao J, Hu HM. Alpha-alumina nanoparticles induce efficient autophagy-dependent cross-presentation and potent antitumour response. Nat Nanotechnol 2011; 6(10): 645-50.

[http://dx.doi.org/10.1038/nnano.2011.153] [PMID: 21926980]

[88] Huang W, Yang X, Yao S, et al. Reactive oxygen species burst induced by aluminum stress triggers mitochondria-dependent programmed cell death in peanut root tip cells. Plant Physiol Biochem 2014; 82: 76-84. [http://dx.doi.org/10.1016/j.plaphy.2014.03.037] [PMID: 24907527]

[89] Matsumoto H, Motoda H. Aluminum toxicity recovery processes in root apices. Possible association with oxidative stress. Plant Sci 2012; 185-186: $1-8$. [http://dx.doi.org/10.1016/j.plantsci.2011.07.019] [PMID: 22325861]

[90] Zhan J, Li W, He HY, Li CZ, He LF. Mitochondrial alterations during Al-induced PCD in peanut root tips. Plant Physiol Biochem 2014; 75: 105-13.

[http://dx.doi.org/10.1016/j.plaphy.2013.12.010] [PMID: 24398246]

[91] Kumar V, Bal A, Gill KD. Impairment of mitochondrial energy metabolism in different regions of rat brain following chronic exposure to aluminium. Brain Res 2008; 1232: 94-103. [http://dx.doi.org/10.1016/j.brainres.2008.07.028] [PMID: 18691561]

[92] Ding WX, Yin XM. Mitophagy: Mechanisms, pathophysiological roles, and analysis. Biol Chem 2012; $393(7): 547-64$. [http://dx.doi.org/10.1515/hsz-2012-0119] [PMID: 22944659]

[93] Tschopp J. Mitochondria: Sovereign of inflammation? Eur J Immunol 2011; 41(5): 1196-202. [http://dx.doi.org/10.1002/eji.201141436] [PMID: 21469137] 
[94] Matzinger P. The danger model: A renewed sense of self. Science 2002; 296(5566): 301-5. [http://dx.doi.org/10.1126/science.1071059] [PMID: 11951032]

[95] Powell BS, Andrianov AK, Fusco PC. Polyionic vaccine adjuvants: Another look at aluminum salts and polyelectrolytes. Clin Exp Vaccine Res 2015; 4(1): 23-45. [http://dx.doi.org/10.7774/cevr.2015.4.1.23] [PMID: 25648619]

[96] Kool M, Soullié T, van Nimwegen M, et al. Alum adjuvant boosts adaptive immunity by inducing uric acid and activating inflammatory dendritic cells. J Exp Med 2008; 205(4): 869-82. [http://dx.doi.org/10.1084/jem.20071087] [PMID: 18362170]

[97] Stacchiotti A, Rodella LF, Ricci F, Rezzani R, Lavazza A, Bianchi R. Stress proteins expression in rat kidney and liver chronically exposed to aluminium sulphate. Histol Histopathol 2006; 21(2): 131-40. [PMID: 16329037]

[98] Gardella S, Andrei C, Ferrera D, et al. The nuclear protein HMGB1 is secreted by monocytes via a non-classical, vesicle-mediated secretory pathway. EMBO Rep 2002; 3(10): 995-1001. [http://dx.doi.org/10.1093/embo-reports/kvf198] [PMID: 12231511]

[99] Le Naour F, Hohenkirk L, Grolleau A, et al. Profiling changes in gene expression during differentiation and maturation of monocyte-derived dendritic cells using both oligonucleotide microarrays and proteomics. J Biol Chem 2001; 276(21): 17920-31. [http://dx.doi.org/10.1074/jbc.M100156200] [PMID: 11279020]

[100] Levy R, Shohat L, Solomon B. Specificity of an anti-aluminium monoclonal antibody toward free and protein-bound aluminium. J Inorg Biochem 1998; 69(3): 159-63.

[http://dx.doi.org/10.1016/S0162-0134(97)10013-7] [PMID: 9629674]

[101] Roth J, Vogl T, Sorg C, Sunderkötter C. Phagocyte-specific S100 proteins: A novel group of proinflammatory molecules. Trends Immunol 2003; 24(4): 155-8. [http://dx.doi.org/10.1016/S1471-4906(03)00062-0] [PMID: 12697438]

[102] Sorci G, Bianchi R, Riuzzi F, et al. S100B Protein, A Damage-Associated Molecular Pattern Protein in the Brain and Heart, and Beyond. Cardiovasc Psychiatry Neurol 2010.

[103] Lindquist S, Craig EA. The heat-shock proteins. Annu Rev Genet 1988; 22: 631-77. [http://dx.doi.org/10.1146/annurev.ge.22.120188.003215] [PMID: 2853609]

[104] Jiang Y, Dey S, Matsunami H. Calreticulin: Roles in cell-surface protein expression. Membranes (Basel) 2014; 4(3): 630-41. [http://dx.doi.org/10.3390/membranes4030630] [PMID: 25230046]

[105] Saptarshi SR, Duschl A, Lopata AL. Interaction of nanoparticles with proteins: Relation to bio-reactivity of the nanoparticle. J Nanobiotechnology 2013; 11: 26.

[http://dx.doi.org/10.1186/1477-3155-11-26] [PMID: 23870291]

[106] Levi R, Wolf T, Fleminger G, Solomon B. Immuno-detection of aluminium and aluminium induced conformational changes in calmodulin-implications in Alzheimer's disease. Mol Cell Biochem 1998; 189(1-2): 41-6. [http://dx.doi.org/10.1023/A:1006887809463] [PMID: 9879652]

[107] Zhen Y, Qi JL, Wang SS, et al. Comparative proteome analysis of differentially expressed proteins induced by Al toxicity in soybean. Physiol Plant 2007; 131(4): 542-54.

[http://dx.doi.org/10.1111/j.1399-3054.2007.00979.x] [PMID: 18251846]

[108] Oh MW, Roy SK, Kamal AH, et al. Proteome analysis of roots of wheat seedlings under aluminum stress. Mol Biol Rep 2014; 41(2): 671-81. [http://dx.doi.org/10.1007/s11033-013-2905-8] [PMID: 24357239]

[109] Zheng L, Lan P, Shen RF, Li WF. Proteomics of aluminum tolerance in plants. Proteomics 2014; 14(4-5): 566-78. [http://dx.doi.org/10.1002/pmic.201300252] [PMID: 24339160]

[110] Wang W, Vinocur B, Shoseyov O, Altman A. Role of plant heat-shock proteins and molecular chaperones in the abiotic stress response. Trends Plant Sci 2004; 9(5): 244-52.

[http://dx.doi.org/10.1016/j.tplants.2004.03.006] [PMID: 15130550]

[111] Wang CY, Shen RF, Wang C, Wang W. Root protein profile changes induced by Al exposure in two rice cultivars differing in Al tolerance. J Proteomics 2013; 78: 281-93. [http://dx.doi.org/10.1016/j.jprot.2012.09.035] [PMID: 23059537]

[112] Lima PD, Leite DS, Vasconcellos MC, et al. Genotoxic effects of aluminum chloride in cultured human lymphocytes treated in different phases of cell cycle. Food Chem Toxicol 2007; 45(7): 1154-9. [http://dx.doi.org/10.1016/j.fct.2006.12.022] [PMID: 17321660]

[113] Mihaljević Z, Ternjej I, Stanković I, Kerovec M, Kopjar N. Application of the comet assay and detection of DNA damage in haemocytes of medicinal leech affected by aluminium pollution: A case study. Environ Pollut 2009; 157(5): 1565-72. [http://dx.doi.org/10.1016/j.envpol.2009.01.002] [PMID: 19200629]

[114] Sharma DR, Sunkaria A, Wani WY, et al. Aluminium induced oxidative stress results in decreased mitochondrial biogenesis via modulation of PGC-1 $\alpha$ expression. Toxicol Appl Pharmacol 2013; 273(2): 365-80. [http://dx.doi.org/10.1016/j.taap.2013.09.012] [PMID: 24084166] 
[115] Burklew CE, Ashlock J, Winfrey WB, Zhang B. Effects of aluminum oxide nanoparticles on the growth, development, and microRNA expression of tobacco (Nicotiana tabacum). PLoS One 2012; 7(5): e34783. [http://dx.doi.org/10.1371/journal.pone.0034783] [PMID: 22606225]

[116] Vecchi S, Bufali S, Skibinski DA, O’Hagan DT, Singh M. Aluminum adjuvant dose guidelines in vaccine formulation for preclinical evaluations. J Pharm Sci 2012; 101(1): 17-20. [http://dx.doi.org/10.1002/jps.22759] [PMID: 21918987]

[117] Murakami M, Hirano T. The molecular mechanisms of chronic inflammation development. Front Immunol 2012; 3: 323. [http://dx.doi.org/10.3389/fimmu.2012.00323] [PMID: 23162547]

\section{(C) 2018 Danielsson et al.}

This is an open access article distributed under the terms of the Creative Commons Attribution 4.0 International Public License (CC-BY 4.0), a copy of which is available at: (https://creativecommons.org/licenses/by/4.0/legalcode). This license permits unrestricted use, distribution, and reproduction in any medium, provided the original author and source are credited. 